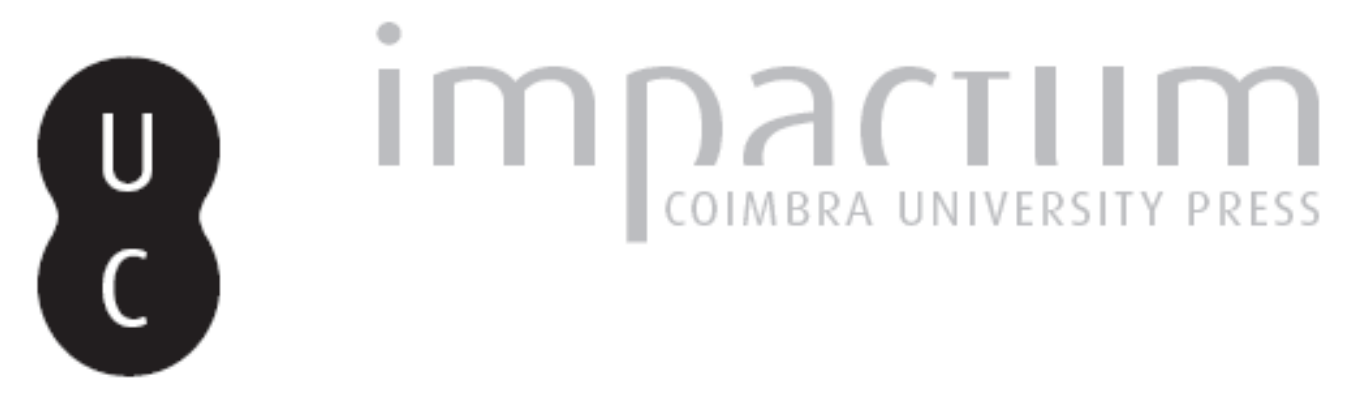

\title{
A crise de 1245
}

\section{Autor(es): Mattoso, José}

Publicado por: Imprensa da Universidade de Coimbra

URL persistente:

URl:http://hdl.handle.net/10316.2/43816

DOI:

DOI:https://doi.org/10.14195/2183-8925_6_1

Accessed : $\quad$ 26-Apr-2023 09:16:26

A navegação consulta e descarregamento dos títulos inseridos nas Bibliotecas Digitais UC Digitalis, UC Pombalina e UC Impactum, pressupõem a aceitação plena e sem reservas dos Termos e Condições de Uso destas Bibliotecas Digitais, disponíveis em https://digitalis.uc.pt/pt-pt/termos.

Conforme exposto nos referidos Termos e Condições de Uso, o descarregamento de títulos de acesso restrito requer uma licença válida de autorização devendo o utilizador aceder ao(s) documento(s) a partir de um endereço de IP da instituição detentora da supramencionada licença.

Ao utilizador é apenas permitido o descarregamento para uso pessoal, pelo que o emprego do(s) título(s) descarregado(s) para outro fim, designadamente comercial, carece de autorização do respetivo autor ou editor da obra.

Na medida em que todas as obras da UC Digitalis se encontram protegidas pelo Código do Direito de Autor e Direitos Conexos e demais legislação aplicável, toda a cópia, parcial ou total, deste documento, nos casos em que é legalmente admitida, deverá conter ou fazer-se acompanhar por este aviso. 


\section{REVISTA DE HISTORIA DAS IDEIAS 6}

\section{. \\ REVOLTAS E REVOLUCOEES}

*

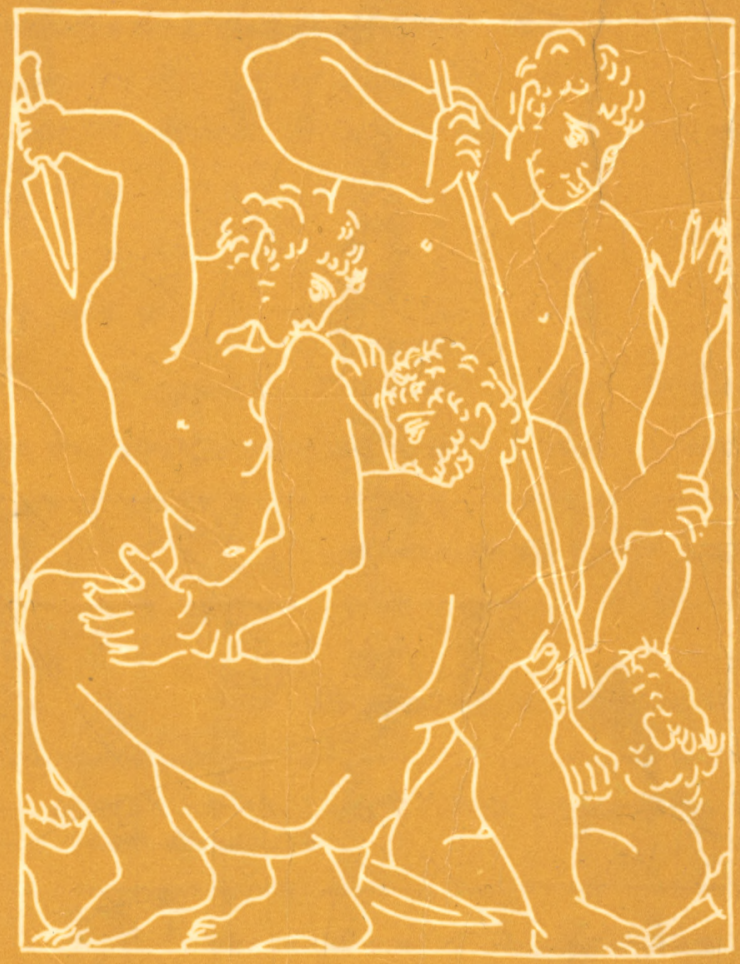

INSTITUTO DE HISTORIA E TEORIA DAS IDEIAS FACULDADE DE LETRAS 
JOSE MATTOSO *

\section{A CRISE DE $1245^{* *}$}

A crise que acompanhou a sucessão de Sancho II é uma das mais conhecidas da nossa história. No entanto, quando se procuram verificar as causas da guerra civil que então se deu, tem sempe de se recorrer a Herculano: depois dele tudo o que se escreveu sobre o tema diz respeito a pormenores secundários. 0 leitor moderno fica, naturalmente, insatisfeito com uma exposição mais do que centenária. Depressa se apercebe que nem Herculano nem os seus continuadores se debruçaram suficientemente sobre os aspectos sociais da crise, que estes são o pano de fundo das lutas políticas, e que a história social tem feito demasiados progressos para ficarmos ainda no nível historiográfico do século XIX.

A nossa curiosidade é ainda suscitada pelo facto de vários estudos recentes terem mostrado a importância dos antagonismos e tensões para o conhecimento das estruturas sociais e do seu funcionamento. Não é por acaso que o tema da mutação social se tornou tão importante para sociólogos e historiadores. Para sociólogos como G. Rocher, J. Ellul ou Monnerot, para citar só alguns franceses; para historiadores como G. Fourquin, M. Mollat, R. Hilton ou R. Pastor de Togneri, para citar só medievalistas.

A partir das interpretações dadas por Marx e pelos primeiros marxistas aos fenómenos revolucionários, baseadas num número limitado de casos, alargourse a visão das muta-

\footnotetext{
* Faculdade de Ciências Sociais e Humanas da Universidade Nova de Lisboa.

** Texto preparado para a lição das provas de agregação apresentadas na Faculdade de Ciências Sociais e Humanas da U.N.L. em 6 de Março de 1979.
} 
ções sociais, descobriram-se outros tipos de conflitos além das lutas de classes, e estudaram-se as suas causas em todas as épocas. Dentre estes conflitos, interessam-nos particularmente os que opõem grupos humanos dentro das mesmas classes. Para fazer a análise das transformações sociais, não basta ter em conta os interesses económicos ligados à produção, mas também outros factores que podem afectar a própria estrutura de uma ou mais classes, como a evolução demográfica ou o regime matrimonial e de parentesco. É necessário também ter em conta as formas assumidas pelas mutações em virtude da intervenção de agentes voluntários como as elites, os "movimentos sociais» ou os grupos de pressão. Devemos, finalmente, analisar o papel das formulações conceptuais mais ou menos sistemáticas, como as ideologias conservadoras ou contestatárias e as utopias escritas ou vividas.

Com efeito, quando se estuda um pouco de perto a sociedade medieval, verifica-se que ela, longe de constituir um corpo estável, ao contrário do que dão a entender as ideologias que tendam a consagrar a ordem estabelecida, está sujeita a numerosas tensões, quer entre as classes sociais, quer entre os grupos que as compõem, em particular a classe dominante. Bem depressa se verifica, também, que no jogo de forças entram todos os elementos que acabo de citar, apesar do aspecto moderno que revestem as fórmulas dos sociólogos. Ora, não há momento mais favorável a uma observação histórica que procure romper o véu da ideologia conservadora, do que uma crise, durante a qual as forças sociais abandonam os equilíbrios instáveis, e se polarisam em torno de fulcros por ventura ocultos noutras ocasiões.

Pareceu-me, portanto, que a crise de 1245 merecia um estudo cuidadoso, capaz de suscitar algumas observações fundamentais do ponto de vista histórico.

Começarei por enunciar as interpretações dadas pelos principais historiadores a esta crise.

O interesse por ela vem de longe. Já se lhe refere a primeira fonte cronística portuguesa, a perdida Crónica Galego-portuguesa de Espanha e de Portugal, no princípio do século XIV, que conhecemos, neste ponto, através do fragmento intitulado IV Crónica Breve de Santa Cruz de Coimbra. Esta fonte atribui a deposição de D. Sancho II pelo Papa ao facto de que ele "nom fazia justiça nem ũa». Merece a pena atentar nesta fórmula e não a pôr rapidamente de lado por parecer reflexão de clérigo para justificar o procedimento papal. 0 autor entende, certamente, por "justiça» não tanto o exercício do poder judicial, mas sobretudo a garantia da ordem e a 
manutenção da equidade, tal como esta se entendia correntemente na época. Implica, portanto, a ideia de que Sancho II, ou era responsável pela infracção da ordem estabelecida, ou era impotente para dominar os factores de desordem que no seu tempo rebentaram.

Tal interpretação transmite-se a todas as fontes cronísticas que dependem daquela: o Livro de Linhagens do Conde D. Pedro, a Crónica de Espanha de $1344 \mathrm{e}$ as suas derivadas e a Crónica de 1419. Foi, porém, invertida com a introdução de outros esquemas mentais na época moderna. Fr. António Brandão, na Monarquia Lusitana, fornece muitos elementos objectivos para reconstituir os acontecimentos, publica fontes importantes, mas procura sobretudo, como bom defensor da autoridade régia, ilibar tanto quanto possível a pessoa de D. Sancho, embora não vá até ao ponto de contestar a legitimidade da sua deposição. Duzentos anos mais tarde, o Cardeal Saraiva dá justamente este passo, tentando mostrar que o papado tinha intervido abusivamente na vida política portuguesa e não dera ouvidos a quem tentara defender o rei.

Ora esta posição em torno de um juízo de valor condiciona a maioria das interpretações dadas até aos nossos dias. A começar, naturalmente, por Herculano. $\mathbf{O}$ grande historiador descreve as manifestações de anarquia, reconhece a incapacidade política de D. Sancho, esboça mesmo explicações baseadas numa pretensa oposição entre uma nobreza de velha cepa, que caracteriza como fidalgos de Além Douro, e nobres mais recentes, mas preocupa-se sobretudo em acentuar o carácter abusivo da intervenção papal e a superioridade moral dos alcaides fiéis ao rei. Não perde nenhuma ocasião para dar largas às suas opiniões anti-clericais.

Dois membros do clero, o P. ${ }^{e}$ L. Gonzaga de Azevedo, Jesuíta, e o P e A. Domingues de Sousa Costa, Franciscano, em 1938 e em 1963 procuraram defender apologeticamente a posição contrária. Embora a erudição de ambos os tivesse levado a aperfeiçoar o quadro factual e a acumular referências documentais, nada dizem acerca das causas profundas da crise. 0 primeiro deles, todavia, não só aceita, mas até multiplica os indícios de anarquia.

Podem-se associar a estas duas obras, as contribuições de outros autores que estudam dados parciais da questão, sem entrarem na polémica clerical mas também sem se referirem a aspectos sociais: Carolina Michaëlis de Vasconcelos que em 1924 falou das cantigas de escárneo em torno de Sancho II; A. E. Reuter, que em 1928 estudou minuciosamente as lutas entre a coroa e os bispos durante o século XIII; e E. Peters, 
que em 1970 mostrou a evolução do tema rex inutilis na lei e na literatura medievais.

A maioria destes trabalhos não exerceram, de resto, qualquer influência sobre as histórias gerais de Portugal. De Fortunato de Almeida a Veríssimo Serrão, os autores continuam a tratar apenas dos aspectos políticos da questão, exprimindo, por vezes as suas opiniões a respeito da polémica clerical. Só Oliveira Marques se preocupa com o aspecto social, sem encontrar elementos suficientes para o definir com segurança, mas apontando para a necessidade de o estudar.

Como se vê, e abstraindo da historiografia medieval, que merece mais consideração do que a que se lhe tem dado, os autores, quando não se perderam em juízos de valor conforme as suas opiniões pessoais, limitaram-se a estudar a crise política. Esta está, parece-me, suficientemente esclarecida. Resta portanto estudar o seu contexto social, terreno praticamente inexplorado até hoje.

Começarei por fazer notar, como introdução ao problema, que entramos aqui num terreno cheio de contradições. Utilizando só factos bem conhecidos, apontarei, por exemplo, que Afonso III foi escolhido pelo clero, mas em breve arranjou conflitos com ele. Durante a guerra civil, apoia-se nos concelhos e na pequena nobreza, mas a alta nobreza parece estar também contra Sancho II. E no entanto, este conserva numerosos partidários que resistem energicamente ao curador e defensor do reino e a animosidade contra ele está bem expressa nas violentas cantigas de escárneo que chegaram até nós. Qual era, portanto, a base do conflito? Que interesses se defendiam? Haverá alguma relação entre a forma como se desenrola a guerra civil e a anarquia de que falam as bulas papais? De resto, havia efectivamente anarquia? As bulas não exageraram? Não se tratou simplesmente de luta pelo poder?

$\mathrm{Na}$ minha opinião houve, na realidade, uma crise social agravada pela crise política. Tentarei demonstrar que a agitação social foi provocada por um desequilíbrio momentâneo entre o crescimento demográfico e os recursos ezonómicos do país. Este desequilíbrio levaria a perturbações mais evidentes no seio da classe dominante, que veria a sua posição social vacilar em virtude de tais contradições. Mas a reestruturação da nobreza acaba por lhe permitir vencer a crise e assegurar a supremacia social, embora com alguns sacrifícios e não pequenos choques de interesses.

Este breve enunciado da minha tese deixa de lado, é claro, muitos pormenores importantes. $\mathrm{Na}$ minha exposição tentarei tê-los em conta, de modo a não perder de vista a 
complexidade dos acontecimentos. Antes, porém, de abordar a análise que baseia a minha interpretação, convém recordar brevemente os principais acontecimentos.

A crise política tem antecedentes remotos. Podemos encontrá-los já desde o princípio do reinado de Afonso II, em 1211. Ainda há pouco o Prof. Torquato de Sousa Soares, numa comunicação à Academia da História, acentuou os conflitos que provavelmente rebentaram nesse momento. $\mathrm{Na}$ sua opinião, baseada, de resto, em Herculano, ter-se-ia constituído um partido que reivindicava a sucessão para o infante Pedro Sanches, com o pretexto de que o primogénito, Afonso II, era leproso.

Mas o afastamento do infante não resolveu a questão: alguns fidalgos portugueses juntaram-se a Afonso IX de Leão nas lutas fronteiriças desse ano e do seguinte. Depois, outros nobres, alguns deles vindos do exílio que deve ter começado por aqueles anos, apoiam, de armas na mão, as irmãs do rei, durante a polémica acerca do cumprimento do testamento paterno.

Outros aspectos do reinado de Afonso II são mais conhecidos: aqueles que têm sido interpretados como indícios da centralização do poder, em detrimento da nobreza e do clero: as inquirições, as confirmações e as leis gerais inspiradas nos princípios do direito romano defendidos pelo chanceler Julião e pelos seus sucessores no mesmo cargo.

Outros finalmente, creio não terem sido ainda clarar mente notados: a constante presença de um grupo de nobres que subscreve os diplomas régios e que não pertenciam às mesmas famílias que rodeiam D. Afonso Henriques e Sancho I. Este facto, de resto, era de esperar: seria muito estranho qualquer propósito centralizador, que partisse apenas do rei e dos seus conselheiros jurídicos, sem o apoio de uma parte da nobreza. $O$ que está, até agora, por estudar são as características sociais deste grupo e por que razão se separa dos outros nobres. De qualquer maneira, porém, os antagonismos no seio da nobreza vêm de longe: começam já no princípio do século XIII.

Com a morte de Afonso II, em 1223, triunfa, parece, o grupo que contestava a política centralizadora. 0 novo rei, Sancho II, que tem apenas 13 anos, fica sujeito às orientações do arcebispo de Braga e faz um acordo com as suas tias. 
Três anos mais tarde, em 1226, o grupo que o rodeava retoma a guerra contra o Islão, provavelmente para reforçar a sua posição política. Mas a expedição contra Elvas foi, segundo parece, mal sucedida, e portanto, em vez de resolver os conflitos deve tê-los agravado. No ano seguinte o infante D. Afonso, futuro conde de Bolonha, deixa o País. Ao mesmo tempo, multiplicavam-se os problemas de natureza eclesiástica, que eram suficientemente graves para trazerem à Península o legado papal João de Abbeville, que entre Portugal, Leão e Castela, passou os anos de 1227 a 1229.

Terminada esta legacia, e cumprindo as repetidas exortações de Abbeville e do próprio Papa, Sancho II retoma a Guerra Santa, agora tornada mais fácil depois da tomada de Cáceres, Badajoz e Mérida pelas tropas leonesas. Assim, ou em expedições dirigidas pelo rei ou pela Ordem de Santiago, os portugueses ocupam rapidamente todo o Alentejo: em menos de dez anos chegam a Tavira.

Pela mesma época, vão-se tornando mais frequentes perturbações e conflitos de vária ordem, no campo eclesiástico e civil. E assim, alguns autores, na esteira de Herculano, vêem nas ausências de Sancho II no campo de batalha, a razão da anarquia que não cessa de alastrar. A guerra externa causaria, por assim dizer um vácuo político. Mesmo que esta interpretação tivesse alguma razão de ser, dificilmente se pode admitir que a fraqueza do poder central pudesse só por si levar a tais consequências se não houvesse também razões de carácter sozial na origem dessas perturbações.

Efectivamente, a partir de 1226 , tem-se conhecimento de lutas entre membros da nobreza; depois de 1233 há várias questões entre os burgueses do Porto e o seu bispo, de vários bispos entre si, a propósito dos limites das suas dioceses, de membros do clero secular contra ordens mendicantes, de bispos com ordens monásticas, etc. Verifica-se, portanto, que a legação de Abbeville, longe de resolver, sequer, os conflitos eclesiásticos, deixara intactos os germens de todas estas tensões. De resto, já nesta época aparecem conflitos mais graves e que ultrapassam o âmbito clerical e da aristocracia: violências de várias ordem contra igrejas e mosteiros, abusos do poder senhorial em muitos lugares, dentro e fora dos reguengos e terras da coroa, e até actos de puro banditismo. Além disso, a partir de 1237, agravam-se, depois de vários episódios esporádicos, as lutas do rei contra os bispos das dioceses de Lisboa, Guarda e Braga.

Estes últimos conflitos atenuam-se a partir de 1241. Depois deste ano, a documentação régia, e mesmo de outras 
fontes, torna-se muito escassa, o que pode significar, talvez, o crescente descontrole do poder político.

Em 1245, porém, os acontecimentos políticos precipitam-se: em Fevereiro, por sugestão do Conde de Bolonha, o Papa Inocêncio IV, recém eleito, declara a nulidade do matrimónio de D. Sancho com D. Mécia Lopes de Haro. Um mês depois, a bula Inter alia desiderabilia descreve nos termos mais dramáticos a anarquia do reino, e ameaça o soberano de que serão tomadas medidas severas se não lhe puser cobro. Finalmente, decorridos apenas quatro meses, em 24 de Julho de 1245, pela bula Grandi non immerito, Inocêncio IV confia a administração do reino ao conde de Bolonha. Fazia-o poucos dias depois de encerrado o concílio de Lião, no qual acabara de afirmar da maneira mais categórica a supremacia do poder eclesiástico sobre o poder temporal, excomungando e destituindo Frederico II do trono alemão.

Começa então a guerra civil. Em Agosto de 1245, não se sabe se antes ou depois de a bula de deposição ter chegado a Portugal, houve em Gaia um sangrento combate entre duas facções nobres, do qual ficou vencedor o valido do rei, Martim Gil de Soverosa, e em que morreram, entre outros, o bastardo régio Rodrigo Sanches. Por seu lado, os bispos e nobres que tinham ido ao concílio de Lião encontravam-se em Paris com o Conde de Bolonha e exigiam-lhe que jurasse em primeiro lugar restabelecer a justiça, e depois respeitar as liberdades eclesiásticas. O Conde partiu algum tempo depois para Lisboa, onde chegou em Dezembro, e iniciou uma campanha militar, porque uma grande parte do País não aceitou a determinação papal. Seguem-se vários episódios, entre os quais avultam a resistência ou a traição de vários alcaides de castelos da Beira, louvados ou verberados por cantigas de maldizer e nos livros de linhagens, e ainda a intervenção de tropas castelhanas conduzidas pelo infante D. Afonso, futuro rei Afonso X, o Sábio. Finalmente, D. Sancho II abandona Portugal no fim do ano 1247. Conhece-se bem o desfecho da guerra civil, com a morte do rei em Toledo, em Janeiro do ano seguinte. Afonso III inicia então, já como rei, uma política de pacificação e de centralização, cujos primeiros actos são a ocupação do resto do Algarve e as cortes de Guimarães de 1250. Neste momento, a sua tarefa ainda não estava concluída, porque os bispos de Braga, Guarda e Coimbra exigem-lhe medidas contra o banditismo nas suas dioceses. De resto ela só pode realizar-se com o fortalecimento do poder régio, o que já começava a suscitar protestos de bispos e de membros da nobreza. 
Eis os acontecimentos mais importantes. Tentemos agora examinar mais de perto os factos sociais, que neste relato mencionámos muito brevemente.

Comecemos por circunscrevê-los geograficamente. Com efeito, e falando, por agora, em termos gerais, as perturbações e violências, parecem ser mais frequentes no Norte do País: no Minho, na Beira Alta, em Trás-os-Montes. Esta verificação coincide, de resto, com a informação expressa que foi dada pelo bispo do Porto em 1237 ao capítulo provincial dos Dominicanos reunido em Burgos, e que menciona toda a espécie de violências praticadas por praedones nas dioceses de Braga, Porto e Lamego. Conhecemos também desmandos praticados por funcionários régios e pelo infante Fernando de Serpa em Lisboa, mas estes eram provavelmente actos isolados e que se explicam pelo conflito entre o rei e o bispo. Mais adiante veremos, porém, que se podem ainda fazer algumas distinções regionais para determinados tipos de conflitos.

Se passamos a considerar o desenrolar dos factos globais, do ponto de vista cronológico, verificamos que a agitação vem de longe: no seio da nobreza, pelo menos em torno do controle do poder político, desde o princípio do reinado de Afonso II. Estendendo-se a lutas entre famílias, aparentemente sem ligação com o domínio político, e a vários tipos de tensões de carácter eclesiástico, desde antes da legacia de João de Abbeville em 1227. Sob a forma de agitação social mais ou menos anárquica, desde antes de 1237. Com o carácter de guerra civil entre 1245 e 1248. Há, portanto, um crescendo na frequência, na intensidade e no âmbito social da agitação. Não se pode, porém, deixar de notar, que os primeiros sintomas se localizam na zona das relações entre a classe dominante e o poder político.

Feitas estas observações genéricas, para o enquadramento dos factos sociais no espaço e no tempo, passemos a analisar os diversos tipos de conflitos, afim de determinar, se possível a sua natureza.

Veremos sucessivamente: as lutas entre o rei e os bispos, entre bispos e burgueses, entre nobres e igrejas ou mosteiros, dos nobres entre si, dos nobres contra vilãos dos concelhos e finalmente os actos de banditismo.

Em primeiro lugar, as lutas do rei com os bispos. Vêm já desde a época de Afonso II e prolongar-se ão durante o reinado de Afonso III. Bastante bem conhecidas, sobretudo desde um trabalho infelizmente muito pouco difundido de 
Abiah Reuter, e de outro de A. Domingues de Sousa Costa, interessam-nos relativamente pouco. Têm a sua origem na aplicação dos novos preceitos do Direito Canónico codificados por Graciano já no século XII, mas que penetraram lentamente nas instituições por intermédio do ensino clerical universitário, e da nomeação de muitos bispos formados em Pádua ou Bolonha que eram seus zelosos defensores. Isto acontece também entre nós, pois alguns dos protagonistas mais activos na luta foram justamente canonistas de renome europeu, como Silvestre Godinho, Vicente Hispano e Pedro Portucalense. Estes princípios, que receberam uma consagração oficial com a publicação das Decretais de Gregório IX, provocaram em vários pontos da Cristandade resistências semelhantes. Resultaram da deslocação da fronteira entre a jurisdição civil e a eclesiástica, o que explica as violências praticadas por ambos os lados. Mas não se lhes pode atribuir um carácter estritamente social; deve-se apenas admitir que tenham contribuído para um quadro de agitação se esta existisse já por outros motivos.

As lutas entre burgueses e bispos, que se verificaram no Porto e em Guimarães, com episódios quentes já desde o fim do século XII, são também demasiado localizadas para se poderem generalizar. Resultam do bem conhecido esforço dos primeiros burgueses para se libertarem dos direitos senhoriais nas cidades sujeitas à jurisdição civil do bispo. Só podiam existir em meios urbanos mais progressivos, ainda raros naquela época, e não eram de natureza a estenderem-se a outros locais e outros meios sociológicos. Estão, portanto, no mesmo caso das anteriores, isto é, podiam ter agravado a agitação social, se ela já existisse.

Pelo contrário, os abusos praticados por nobres sobre igrejas e mosteiros, parecem-me ter uma razão social profunda. E uma queixa constante, quase obcessiva, nos documentos eclesiásticos de várias origens, desde o princípio do século XIII. Tendo em conta que o clero, sobretudo o clero monástico, era o principal sustentáculo ideológico da nobreza, e ainda os íntimos laços familiares que uniam os membros de ambos os estados, não podemos deixar de ver nestas violências o recurso um tanto ou quanto desesperado a meios económicos que não se podiam obter facilmente de outra forma.

Se examinarmos estes abusos mais de perto, verificamos que os responsáveis conhecidos são filhos segundos ou bastardos de famílias de várias categorias, sem excluir as mais nobres, mas sobretudo fidalgos não referidos nos nobiliários, o que permite afirmar que se incluem nas categorias inferio- 
res da nobreza. Podemos, assim, identificá-los ou com aqueles juvenes tão magistralmente caracterizados por G. Duby, isto é, filhos segundos marginalizados pelas estruturas familiares, ou com cavaleiros de poucos recursos, esses a que os livros de linhagens chamam cavaleiros de um escudo e uma lança. Sabemos que as violências deste tipo, praticadas por esta espécie de "proletariado nobre", como diz R. Fossier, existem por toda a parte e já desde o século XI. Canalizados para o exterior, para as cruzadas, ordens militares ou a peregrinação, ou enquadrados em organizações especiais como os séquitos reais e senhoriais e as ordens monásticas, não se manifestam em Portugal antes do fim do século XII, devido, certamente, a razões que apresentarei na última parte desta exposição.

Um quarto tipo de conflitos é o dos nobres entre si. Analisados os nomes e linhagens que neles participam, verifica-se que tais lutas nem sempre estão ligadas ao propósito de controlar o poder político: algumas tomam a forma de vingança privada. Também não se vê que os contendores se oponham por categorias sociais dentro da nobreza, apesar do que Herculano sugere em determinado ponto da História de Portugal, nem mesmo por grupos de famílias de regiões diferentes, um constituído por nobres de Além Douro, outro pelos da Beira, como ele admite também noutro passo. Verificamos, pelo contrário, que a pequena e média nobreza têm partidários nos dois campos, pró e contra D. Sancho II. Parece mesmo verificar-se que os pequenos nobres e filhos segundos exercem um papel mais activo do que os chefes de linhagens importantes, qualquer que seja o partido em que se situam. A família dos Portocarreiros, oferece disto a prova mais evidente. E neste momento uma família sem tradições, com muitos membros e provavelmente com poucos recursos. Ora ela fornece três irmãos a um partido, e dois outros, primos direitos deles, ao partido oposto. Assim, foi Portocarreiro o arcebispo de Braga, D. João Egas que esteve no concílio de Lião e em Paris; seu irmão Raimundo ou Reimão encarregou-se de raptar a rainha D. Mécia e de a levar para Ourém. Mas os primos deles não defendem com menos vigor a causa de D. Sancho: Gomes Anes é especialmente censurado num inquérito de 1252 pelas violências praticadas em Coimbra durante a guerra civil; seu irmão Fernando, deão da Sé de Braga, não suportou o triunfo de Afonso III, exilou-se para Castela e morreu em Burgos em 1272. Ora a agressividade dos Portocarreiros está expressa até nas alcunhas que os membros do primeiro ramo usaram: Lourenço Viegas o Calfeirão, aumentativo do pastor de bando de cabras, ou carneiro inquieto e atrevido, Gonçalo Viegas, o Maça Madeira, Reimão Viegas, o Torres. Os irmãos do arce- 
bispo de Braga constituíam, portanto, um trio digno de figurar num western americano.

Esta observação vem confirmar o que dizíamos há pouco, isto é, que a marginalização dos filhos segundos e os poucos recursos dos pequenos nobres agravavam a sua propensão para a violência e alimentava o antagonismo político. Situação confusa, na qual os interesses em jogo se tornam dificilmente conciliáveis. Os membros do clero, afectados por ela, tenderiam a acentuar a necessidade de um governo forte, contanto que zelasse pela manutenção dos privilégios por ele adquiridos. Os membros da corte, de todas as categorias, procurariam utilizar o poder em favor dos seus protegidos, mas veriam a sua posição fortemente ambicionada por nobres de menos recursos.

Note-se, ainda, para confirmar a interpretação que damos a este tipo de lutas, que os combates entre nobres de que há conhecimento claro se situam no norte do País: na região de Penafiel, em 1226, entre Vasconcelos e Alvelos de um lado, Freitas do outro; na região do Sousa, em 1230, entre Sousas e Soverosas; em Gaia, em 1245, entre Soverosas de um lado, Lumiares, Correias e Toronhos do outro. Quer dizer, nas dioceses do Porto e de Braga, onde a densidade da propriedade nobre era maior e onde, portanto, o choque de interesses no seio da classe podia ser mais violento.

Há ainda outro tipo de conflitos: os abusos e violências cometidos por nobres contra vilãos em senhorias e tenências. Este género de actos está amplamente documentado nas Inquirições de 1258. Herculano fez uma lista exemplificativa; recentemente Almeida Fernandes acrescentou-lhe mais dois ou três casos. Mas a lista poder-se-ia alongar bastante mais. Contentando-nos com os casos já recolhidos, verifica-se que os mais graves destes abusos se dão em regiões periféricas da zona senhorial por excelência, quer dizer, na Beira Alta, Trás-os-Montes e Alto Minho. A localização geográfica aponta, portanto, para uma hipótese que consistiria em relacionar este tỉpo de conflitos com um processo de extensão das exacções senhoriais a regiões onde, até então, predominava a propriedade vilã alodial, e onde existiam, talvez, comunidades rurais suficientemente organizadas para oporem à senhorialização uma resistência maior. Prefiro, todavia, deixar estes casos de lado, à espera de ocasião para, num estudo sistemático, confirmar ou desmentir tal interpretação. Limitar-me-i a observar que, no caso de se confirmar a minha hipótese, se teria de relacionar o processo de extensão geográfica das exacções senhoriais com a necessidade que a nobreza tem de aumentar 
os seus recursos materiais, tendendo, portanto, a exercer 0 direito de banum para além dos seus domínios fundiários.

Mencionarei, finalmente, os actos de puro e simples banditismo, quer dizer, aqueles que os documentos da época atribuem a praedones, raptores ou invasores, nobres e não nobres, portanto de todas as categorias sociais. Eram, evidentemente, marginais e gente fora da lei. Eram os homens sem terra e sem senhor, que já preocupavam o legislador régio em 1211, e que voltam a aparecer como grave ameaça social em 1237, 1245 e 1250, respectivamente numa carta do bispo do Porto, já citada, na bula Inter alia desiderabilia e nos capítulos das cortes de Guimarães, em queixas dos bispos de Braga, Guarda e Coimbra.

Significa este facto que a violência não se restringia à classe nobre e que atingia também as camadas inferiores da população. Denota a existência de grupos não integrados nas estruturas sociais. São, certamente o resultado de um excedente demográfico, que a organização económica da época não consegue sustentar.

Devemos notar, a este propósito, em primeiro lugar, que estas perturbações parecem abranger uma área mais vasta do que as anteriores, porque, segundo se deduz dos capítulos de Guimarães, não atingiam apenas as dioceses do Porto, Braga e Lamego, a que se refere especialmente o bispo do Porto em 1237, mas também as de Guarda e Coimbra. Fasto que não admira, dado que a Beira foi a zona mais atingida pela guerra civil de 1245: é aí que se situam as lutas bem conhecidas, em torno de Coimbra, Celorico, Covilhã, Guarda, Lanhoso, Trancoso, etc. Os combates de Leiria, foram, certamente, os mais meridionais. A guerra deve, portanto, ter deixado o seu rasto de atrocidades e de instabilidade; era com certeza a ocasião mais propícia para as actividades de bandos de salteadores, que não foram facilmente absorvidos depois de feitas as pazes.

Devemos aproximar estas violências das cometidas pelos bandos de cottereaux que o concílio de Latrão de 1179 censura tão asperamente e que pilhavam por conta própria ou eram utilizados como mercenários por reis e senhores no Sul da França durante a segunda metade do século XII. Os bandos deste género aparecerão mais tarde em Castela, e assolam, por exemplo, a região da Jara, entre a Mancha, Castela a Nova e a Estremadura leonesa no fim do século XIII, onde lhe chamam golfines. Entre nós não se identificam com grupos tão caracterizados, mas é inegável a existência de marginais dedicados ao banditismo, e que são incitados à violência pelas lutas e abusos dos senhores e pelas suas própria dificuldades de subsistência. 
Do exposto até aqui, concluímos, portanto, que a propensão para a violência, e até mesmo uma certa anarquia, atingiram quase todo o país, embora com variantes. No Entre Douro e Minho, sobressaem as lutas de que o "proletariado nobre» é o principal protagonista. No Alto Minho, Trás-os-Montes e Beira Alta distinguem-se choques entre senhores e gente dos concelhos. Um pouco por toda a parte, mas talvez com maior incidência na Beira, ao menos depois da guerra civil, o banditismo praticado por marginais. Quais os motivos destas graves perturbações? Como disse ao princípio, ao enunciar a minha hipótese de interpretação, dever-se-iam a um desequilíbrio conjuntural entre o crescimento demográfico e a expansão territorial e económica de um país com recursos limitados. Depois de analisados os factos, resta-me, portanto, mostrar as suas causas.

Começarei por lembrar um facto actualmente bem conhecido de todos os medievalistas: a expansão demográfica da Europa ocidental nos séculos XI a XIII. Apesar de menos esclarecido entre nós, pode, todavia, supôr-se que Portugal foi também atingido pelo mesmo movimento, dado que aparecem também entre nós indícios tais como a emigração portuguesa para cidades leonesas e castelhanas, como Zamora, Salamanca, Badajoz e Sevilha, a presença de numerosos cavaleiros e peões portugueses em grandes batalhas como Navas de Tolosa e o cerco de Sevilha, os progressos do povoamento intercalar na Estremadura, Ribatejo e Beira Baixa durante o século XIII, como mostraram Rui de Azevedo e Orlando Ribeiro, o avanço da reconquista portuguesa no Alentejo precisamente na década de 1230, a continuação dos desbravamentos e plantação de vinhas novas um pouco por toda a parte, a multiplicação de paróquias no campo e nas cidades, etc. Todavia, apesar destes indícios, dificilmente podemos calcular os ritmos de crescimento por períodos definidos ou o volume das migrações internas e da emigração. Apesar destas incertezas, creio poder apresentar alguns argumentos para afirmar que deve ter havido um desequilíbrio conjuntural entre os recursos disponíveis e o crescimento da população durante a primeira metade do século XIII.

Deste desequilíbrio nãc se encontram vestígios antes do fim do século anterior. Com efeito, se a densidade populacional era muito grande no Entre Douro e Minho desde pelo menos o século XI, como se deduz dos censuais de Braga e do Porto, e, depois, das Inquirições, a Reconquista alargou a área territorial, permitindo a fixação de excedentes em zonas 
antes pouco habitadas, sobretudo nas Beiras e na área intercalar da Estremadura e do Ribatejo. Os forais de Afonso I e de Sancho I são o indício de que o povoamento nestas regiões constituía um movimento espontâneo, mas encorajado pelas forças políticas.

A partir do terceiro quartel do século XII, porém, a Reconquista portuguesa esmorece ou conta graves insucessos. $\mathrm{O}$ Tejo permanece como linha fronteiriça durante dezenas de anos, apesar das bolsas que se constituem a sul, em Evora e Alcácer. Tenta-se mais resistir às investidas almóades, do que alargar a zona cristã. Mesmo a tomada de Alcácer do Sal pode ser considerada como a operação necessária à criação de uma cinta de defesa mais eficaz para a cidade de Lisboa. Ora esta paralização do alargamento territorial tem também um paralelo no afrouxamento da política colonizadora, porque Afonso II e Sancho II reduzem consideravelmente a concessão de forais: o rei anterior, Sancho I, tinha dado 42 forais em 25 anos; eles concederam 24 em 38 anos. Ou seja, de uma média de 168 por ano passa-se a 0,63 por ano. Sinal de que a necessidade de povoamento que provavelmente continuava a fazer-se sentir não encontra resposta da parte das forças políticas.

E verdade que a Reconquista avança consideravelmente no tempo de Sancho II, a partir de 1230, quando, em menos de dez anos, se ocupa o resto do Alentejo, e se avança até Tavira. Mas, por um lado, o alargamento da fronteira era ainda demasiado recente para resolver rapidamente o desequilíbrio anterior, por outro lado, até à conquista de Faro, em 1249, não estão ainda criadas as condições suficientes de segurança para atrair a população.

De qualquer maneira, a reconquista e o povoamento constituíam, deserto, soluções que algumas personalidades, pelo menos, propunham conscientemente para resolver o citado desequilíbrio, como é o caso do legado João de Abbeville, que, saindo do âmbito dos problemas clericais, aconselha uma coisa e outra.

De resto, pode-se apontar como contraprova a situação da segunda metade do século XIII, durante a qual se volta ao ponto de equilíbrio. A curva demográfica continuou, provavelmente a subir; mas os recursos económicos aumentaram também consideravelmente. Conquistado o Algarve, retomou-se a emigração para o sul. O rei volta a encorajar o povoamento: assim, Afonso III dá 62 forais em 31 anos, numa média de dois por ano; os senhores, nobres, eclesiásticos e das ordens militares dão, no mesmo período, 21 forais. Além disso, intervêm novos factores económicos, como a maior circular 
ção de bens, permitida pelo activar do comércio e facilitada por maior disponibilidade monetária; e o crescimento das cidades, onde a divisão do trabalho permite aumentar a produção artesanal. Pode mesmo talvez admitir-se que entre nós se tenha dado, como Portela Silva verificou para a diocese de Tuy no mesmo período, um ligeiro aumento dos níveis de produção agrícola, graças à melhoria de processos tecnológicos, como a difusão do arado de ferro, a maior utilização de leguminosas, o aumento do gado, o mais frequente emprego da rega e a melhoria do afolhamento.

Tudo isto se dá ao mesmo tempo que a centralização política levada a cabo por Afonso III facilita um novo enquadramento das forças sociais.

Estas explicações são, todavia, demasiado genéricas para constituírem prova insofismável da minha interpretação. Seria necessário proceder a estudos quantitativos sobre toda a espécie de documentos para a confirmar, modificar ou desmentir.

Entretanto, a situação é mais clara para um sector da sociedade, a nobreza, onde me parece poderem-se encontrar explicações mais definidas da crise.

Neste sector é possível, até, que a conjuntura fosse mais explosiva do que no resto do corpo social. Por um lado pode, provavelmente, admitir-se com Reyna Pastor de Togneri e com L. Genicot, que a taxa de natalidade nobre fosse superior, graças a condições de existência mais favoráveis que alargariam a esperança de vida. Por outro lado, é muito provável que a classe nobre estivesse ainda, pelo menos até ao fim do século XII, mas provavelmente ainda uns anos depois, aberta à inclusão de indivíduos provenientes de outras classes, sobretudo da cavalaria vilã e da ministerialidade. $\mathrm{O}$ número de nobres cresce, assim, duplamente. Mas os recém vindos de uma origem ou de outra, teriam sem dúvida de se contentar com porções menores da herança familiar ou, no caso das nobilitações, de consumirem num apertado luxo os magros recursos acumulados.

Ora, dado que as famílias tradicionais só tardiamente criam domínios nas Beiras e na Estremadura, assiste-se assim a uma degradação de antigas fortunas fragmentadas pela partilha hereditária e a concorrência social da nobreza inferior.

O «proletariado nobre» assim criado, para utilizar a expressão de Fossier, seria, portanto levado a utilizar toda a espécie de recursos para manter a posição social adquirida. Um deles é, como vimos, o assalto de igrejas e mosteiros. Outro, a extensão dos poderes senhoriais em detrimento da propriedade régia e alodial, por meios lícitos como o amádigo, ou ilícitos, como a ocupação de terras ou a extensão dos di- 
reitos senhoriais sobre homens livres. Um trabalho de seminário orientado há pouco pela Dr. ${ }^{\mathrm{a}}$ Iria Gonçalves mostrou a incrível expansão dos direitos senhoriais por meio de amádigo no Alto Minho durante o período que antecedeu as Inquirições de 1258. Outro recurso, ainda, a criação de domínios e senhorias para ramos secundários e bastardos das linhagens, na Beira e na Estremadura.

Além de tudo isto, e de uma maneira mais profunda, os nobres modificam as suas estruturas familiares. Partindo de uma fase em que se encontram ainda muitos vestígios da família larga e da estrutura cognática, tendem, sobretudo a partir de meados do século XII, para adoptar lentamente a sucessão unilinear por via masculina, à semelhança da sucessão régia. Quer dizer, começam a formar-se as linhagens. Mas esta nova estrutura, destinada sobretudo a preservar tanto quanto possível intacto o património familiar, privilegia o promogénito e inferioriza os filhos segundos. Estes ficam na dependência do chefe de linhagem, e evita-se ou retarda-se o seu casamento. Marginalizados na família, encaminham-se para o exílio, para a reconquista leonesa e castelhana, alistam-se nas mesnadas de reis e senhores, na Península ou fora dela (como acontece com vários filhos de Sancho I e com tantos outros), vão engrossar as ordens monásticas ou os cabidos canonicais, tornam-se trovadores ou peregrinos, vão estudar para as universidades, ingressam nas ordens militares, fazem-se cavaleiros andantes. Por isso se encontram tantos cava. leiros portugueses na conquista de Sevilha e na Etremadura leonesa, nas cortes de Fernando III, Afonso X e Sancho IV, por isso prosperam os mosteiros cistercienses femininos destinados à aristocracia, como Arouca, Lorvão, Chelas ou Cós, por isso sobe a proporção de cónegos de origem nobre. Mais ainda: tudo parece indicar que é nesta época que se completam e aperfeiçoam os vários mecanismos de defesa jurídica do património familiar, como a reserva hereditária e a melhora, para benefício da linha sucessória principal, o retracto familiar para impedir a alienação de bens próprios, $o$ princípio da troncalidade, a indivisibilidade das honras, o morgadio, os vínculos.

Esta nova estrutura exprime-se, na onomástica, pela adopção cada vez mais frequente dos nomes de família, que supõem o triunfo e a prática da sucessão agnática e a transmissão integral da honra ou solar no ramo principal da família, costume que se generaliza durante a primeira metade do século XIII.

Além disso verifica-se uma certa propensão para a endogamia, o casamento entre parentes, sobretudo nas camadas 
mais altas da sociedade, como meio de evitar a alienação da herança ou conseguir a sua reconstituição. Contra estes processos, que o Direito Canónico condena severamente, as censuras papais e do legado João de Abbeville de pouco valem. As novas estruturas familiares permitem manter a fortuna, e portanto a posição das linhagens na escala social, mas criam uma porção tanto maior de marginalizados nobres quanto maior é a taxa de natalidade. Enquanto não se criam ou aperfeiçoam os mecanismos destinados a absorver tais excedentes, eles constituem um foco de perigosa agitação e agravam toda a espécie de tensões sociais e políticas. Os resultados de tais mecanismos como é óbvio, só lentamente se verificam.

Voltando-me, finalmente, para os aspectos globais da crise, creio que esta interpretação explica suficientemente tanto o fenómeno no seu conjunto, como as suas características peculiares. Recordemos algumas: o papel que nela toma a pequena nobreza; a maior intensidade de certos tipos de conflitos no Entre Douro e Minho, na periferia desta zona ou nas Beiras; o agravamento de fricções de outra natureza, como os que dividem reis e bispos, burgueses e prelados, ou clérigos entre si; o propósito aparentemente contraditório de o clero colaborar na centralização e defender as liberdades eclesiásticas; as exortações do legado papal ao povoamento e à Guerra Santa; a emigração nobre para Leão e Castela; a multiplicação de mosteiros cistercienses femininos; e até mesmo fenómenos culturais, como o vigor do trovadorismo.

Com a intervenção de Afonso III, o País regressa ao equilíbrio. Já falei na acção de factores de ordem económica que aumentam os recursos disponíveis. Resta-me referir brevemente que, para além dos resultados trazidos pela nova estrutura familiar nobre, aliados a um sistema de absorção dos excedentes, que já mencionei, Afonso III foi também ajudado pelo facto de encontrar uma nobreza já dizimada e enfraquecida pelos conflitos internos, portanto mais disposta a aceitar a intervenção arbitral do rei, e em segundo lugar pelo apoio em famílias de categoria média ou inferior, mas que souberam encontrar nas novas fontes da produção agrícola comercializável o seu sustentáculo económico. O país caminha, assim, para um novo equilíbrio, e mesmo para uma certa prosperidade, de que o rei $D$. Dinis colherá largamente os frutos. 